J. Dairy Sci. 95:2307-2318

http://dx.doi.org/10.3168/jds.2011-4947

(C) American Dairy Science Association ${ }^{\circledR}, 2012$.

\title{
Stability of milk fat globule membrane proteins toward human enzymatic gastrointestinal digestion
}

\author{
T. T. Le, ${ }^{\star} \dagger$ T. Van de Wiele,‡ T. N. H. Do, ${ }^{\star}$ G. Debyser,§ K. Struijs, ${ }^{\star}$ B. Devreese,§ K. Dewettinck, ${ }^{\star}$ \\ and J. Van Camp*1 \\ *Department of Food Safety and Food Quality, Ghent University, Coupure links 653, 9000 Ghent, Belgium \\ †Faculty of Food Science and Technology, Ho Chi Minh City Nong Lam University, Ho Chi Minh City, Vietnam \\ łLaboratory for Microbial Ecology and Technology, Ghent University, Coupure links 653, 9000 Ghent, Belgium \\ §Department of Biochemistry and Microbiology, Ghent University, K. L. Ledeganckstraat 35, 9000 Ghent, Belgium
}

\section{ABSTRACT}

The milk fat globule membrane (MFGM) fraction refers to the thin film of polar lipids and membrane proteins that surrounds fat globules in milk. It is its unique biochemical composition that renders MFGM with some beneficial biological activities, such as anti-adhesive effects toward pathogens. However, a prerequisite for the putative bioactivity of MFGM is its stability during gastrointestinal digestion. We, therefore, subjected MFGM material, isolated from raw milk, to an in vitro enzymatic gastrointestinal digestion. Sodium dodecyl sulfate PAGE, in combination with 2 staining methods, Coomassie Blue and periodic acid Schiff staining, was used to evaluate polypeptide patterns of the digest, whereas mass spectrometry was used to confirm the presence of specific MFGM proteins. Generally, it was observed that glycoproteins showed higher resistance to endogenous proteases compared with non-glycosylated proteins. Mucin 1 displayed the highest resistance to digestion and a considerable part of this protein was still detected at its original molecular weight after gastric and small intestine digestion. Cluster of differentiation 36 was also quite resistant to pepsin. A significant part of periodic acid Schiff 6/7 survived the gastric digestion, provided that the lipid moiety was not removed from the MFGM material. Overall, MFGM glycoproteins are generally more resistant to gastrointestinal digestion than serum milk proteins and the presence of lipids, besides glycosylation, may protect MFGM glycoproteins from gastrointestinal digestion. This gastrointestinal stability makes MFGM glycoproteins amenable to further studies in which their putative health-promoting effects can be explored.

Key words: milk fat globule membrane glycoprotein, gastrointestinal digestion, dialysis, mucin 1

Received September 18, 2011.

Accepted January 9, 2012.

${ }^{1}$ Corresponding author: john.vancamp@ugent.be

\section{INTRODUCTION}

The fat globules in milk are surrounded by a thin membrane, which is called the milk fat globule membrane (MFGM). The lipid fraction of MFGM consists of polar lipids such as glycerophospholipids, sphingolipids, including sphingomyelin and glycolipids (lactosylceramide, galactosylceramide, and gangliosides), cholesterol, and high-melting triglycerides (Singh, 2006). Upon isolation from raw milk, up to $50 \%$ of the MFGM material can be neutral triglycerides (Chandan et al., 1971; Kanno and Kim, 1990; Fong et al., 2007; Le et al., 2009). The high concentration of neutral triglycerides in the isolates is likely derived from the contamination of the core fat during isolation (Walstra, 1985). The major MFGM proteins, separated by SDS-PAGE on the basis of decreasing molecular weights (MW), are mucin 1 (MUC1), xanthine dehydrogenase/oxidase (XDH/XO), periodic acid Schiff (PAS) III, cluster of differentiation 36 (CD36), butyrophilin (BTN), PAS $6 / 7$ or lactadherin, adipophilin (ADPH), proteose peptone 3 (PP3), and FA-binding protein. Xanthine dehydrogenase/oxidase and ADPH are not glycosylated, whereas the others are characterized by different degrees of glycosylation (Mather, 2000). The MFGM is proposed to consist of 3 layers: from the core fat outward, a monolayer of polar lipids with some embedded proteins, a dense proteinaceous coat, and an outer bilayer of polar lipids with embedded proteins (Dewettinck et al., 2008).

Mucin 1, PAS 6/7, and PP3 may inhibit the infection of the gastrointestinal tract system by rotavirus (Kvistgaard et al., 2004; Bojsen et al., 2007; Inagaki et al., 2010). Mucin 1 was also found to inhibit Norwalk virus (Ruvoën-Clouet et al., 2006) and common enteropathogenic bacteria (Escherichia coli, Salmonella enterica serovar Typhimurium, Staphylococcus aureus, and Bacillus subtilis; Parker et al., 2010). It may also prevent the transmission of human immunodeficiency virus (HIV) from mother to child (Habte et al., 2008; Saeland et al., 2009). A protein mixture of bovine 
MFGM was found to inhibit infection of Helicobacter pylori in an experimental mouse model (Wang et al., 2001). Periodic acid Schiff $6 / 7$ and CD36 may play a role in the development of the intestinal immune system of newborns (Yabe et al., 2003; Bu et al., 2007). Lactophoricin (a peptide derived from PP3) was shown to inhibit the growth of various gram-positive (Streptococcus thermophilus) and gram-negative (Salmonella) bacteria but not E. coli (Campagna et al., 2004).

The anti-adhesion properties of MFGM glycoproteins are attributed to their carbohydrate structure, which makes them act as decoy receptors (glycoproteinpathogen interactions) or to possibly compete with pathogens for receptor sites on the epithelial cells. For in vitro studies, a mixture of MFGM proteins or purified MFGM glycoproteins is usually applied. However, in reality, during digestion proteins are subjected to hydrolysis caused by gastrointestinal proteases.

To investigate the disposition of proteins within the MFGM, Kobylka and Carraway (1973) and Shimizu et al. (1979) digested washed fat globules (cream) and MFGM fragments (from buttermilk derived from churning the washed cream) from bovine milk with several proteases and reported that the resistance of MFGM proteins against proteases was different. No essential difference existed in hydrolysis pattern between digestion of washed cream and digestion of isolated MFGM fragments (Kobylka and Carraway, 1973; Shimizu et al., 1979). Mucin 1 was strikingly resistant, whereas CD36 and PAS 6/7 were relatively resistant to pepsin (Shimizu et al., 1979). Vanderghem et al. (2011) treated washed fat globules with trypsin and pronase $\mathrm{E}$ and showed that virtually all BTN and ADPH were hydrolyzed, whereas PAS 6/7 was almost resistant. Recently, Ye et al. (2011) carried out gastric digestion of raw milk, MFGM material was then isolated from the treated milk and it was found that the major MFGM proteins were hydrolyzed at different rates; BTN was released from the fat globule surface more slowly than $\mathrm{XO}$ and PAS 6/7.

The F4-binding capacity (i.e., the capacity to interfere with attachment of F4ac-positive enterotoxigenic $E$. coli to porcine small intestinal villi) of PAS 6/7 remained after treating porcine milk with pepsin but that binding property was abolished after a further treatment with pancreatin (Shahriar et al., 2006). Hamosh et al. (1999) found that MUC1 and PAS 6/7 were stable in the stomach of breast-fed infants, whereas BTN was much more labile. Mucin 1 could be detected in stool specimens from breast-fed infants (Patton, 1994; Hamosh et al., 1999). This indicates that human MUC1 is very resistant to gastrointestinal digestion.

Bovine MFGM material/fragments and lipid-free membrane protein mixtures can be produced on an in- dustrial scale, starting from buttermilk or butter serum (Corredig et al., 2003; Rombaut et al., 2007; Catchpole et al., 2008; Le et al., 2011). To valorize this type of material to be used as functional food ingredient or nutraceutical, it is important to investigate how it behaves in both stomach and intestine. Several studies, as reviewed above, have not considered enzymatic intestinal digestion of MFGM proteins. The main objective of this study was, therefore, to examine the digestion of MFGM proteins during gastric and intestinal digestion. To investigate the role of the lipid fraction in protecting the membrane glycoproteins from digestion, we subjected both whole MFGM fragments and lipid-free protein mixtures, which were obtained from the former by defatting, to gastrointestinal digestion experiments.

\section{MATERIALS AND METHODS}

\section{Materials and Chemicals}

Raw milk was obtained from a local dairy farm within $2 \mathrm{~h}$ after morning milking. Skim milk powder was delivered from Friesland Foods (Lummen, Belgium). The enzymes and the enzyme mixture, namely pepsin (from porcine gastric mucosa, lyophilized powder, 3,260 U/ mg of protein), trypsin (from porcine pancreas, type IX-S, lyophilized powder, 14,800 U/mg of protein), $\alpha$-chymotrypsin (from bovine pancreas, type II, lyophilized powder, $59.3 \mathrm{U} / \mathrm{mg}$ of protein), and pancreatin from porcine pancreas $(4 \times$ US Pharmacopeia specifications) were bought from Sigma-Aldrich (Bornem, Belgium).

\section{Preparation of MFGM Materials}

The whole MFGM material was isolated from raw milk according to the procedure explained by Le et al. (2009). Briefly, the cream obtained (from the fresh milk) after 2 washes was churned into buttermilk and butter. The butter was melted with one-half volume of deionized water at $50^{\circ} \mathrm{C}$ for $1 \mathrm{~h}$. It was then centrifuged at $1,070 \times g$ for $5 \mathrm{~min}$ at $50^{\circ} \mathrm{C}$ into butter serum and butter oil. The buttermilk and butter serum were combined and lyophilized into a powder, called whole MFGM, which was stored at $-40^{\circ} \mathrm{C}$. Part of the whole MFGM was subjected to solvent extraction for removal of the lipids to obtain purified MFGM protein material, called lipid-free membrane protein mixture.

To remove the lipid fraction, the lyophilized whole MFGM material was dispersed in chloroform/methanol $(2 / 1)$ at a ratio of $1 / 20(\mathrm{wt} / \mathrm{vol} ; 20 \mathrm{~mL}$ of the solvent mixture to $1 \mathrm{~g}$ of MFGM material). The sample was then mixed vigorously for 5 min using a magnetic stirrer and centrifuged at $4,050 \times g$ for $5 \mathrm{~min}$. The 
supernatant was removed. The pellet, composed of precipitated protein, was washed twice more with the same solvent mixture at a ratio of $1 / 10(\mathrm{wt} / \mathrm{vol})$. The residue of the solvents in the final pellet was removed under vacuum using a rotary evaporator at $40^{\circ} \mathrm{C}$ and the protein powder was dried further overnight at $30^{\circ} \mathrm{C}$. The obtained lipid-free membrane protein mixture was stored at $-40^{\circ} \mathrm{C}$.

\section{Chemical Analysis}

Determination of Protein Content. Total protein content of the MFGM materials and skim milk powder was determined by measuring the nitrogen content using the Kjeldahl method (AOAC, 2006). The conversion factor for skim milk was 6.38 and for the MFGM materials 7.1 (Walstra et al., 2006). A higher conversion factor was used for MFGM proteins, as they mainly contain glycoproteins.

Determination of Free Amino Groups. The degree of hydrolysis was evaluated by measuring the concentration of free amino groups after reaction with trinitrobenzenesulfonic acid (TNBS; Sigma-Aldrich), following the method of Adler-Nissen (1979). The sample was diluted 10 times in deionized water in an Eppendorf tube and was then centrifuged at 8,160 $\times g$ for $30 \mathrm{~min}$ at $4^{\circ} \mathrm{C}$. The supernatant was further diluted to obtain a concentration of $0.4 \mathrm{mg}$ of total protein/ $\mathrm{mL}$ before measurement. In brief, the procedure was as follows: $0.5 \mathrm{~mL}$ of diluted sample was added to a test tube containing $0.5 \mathrm{~mL}$ borate buffer $[20.12 \mathrm{~g}$ of sodium tetraborate $\left(\mathrm{Na}_{2} \mathrm{~B}_{4} \mathrm{O}_{7}\right.$ dissolved in $1 \mathrm{~L}$ of $\left.0.1 \mathrm{~N} \mathrm{NaOH}\right)$ ]. Twenty microliters of TNBS $0.5 \%$ was added followed by immediate vortexing. The solution was incubated for $10 \mathrm{~min}$ at $20^{\circ} \mathrm{C}$ and then $2 \mathrm{~mL}$ of stop solution [containing $1.5 \mathrm{~mL}$ of sodium thiosulfate $\left(0.1 \mathrm{~N} \mathrm{Na}_{2} \mathrm{~S}_{2} \mathrm{O}_{3}\right)$ and $98.5 \mathrm{~mL}$ of sodium dihydrogen phosphate $(0.1 \mathrm{~N}$ $\mathrm{NaH}_{2} \mathrm{PO}_{4}$ ); prepared daily] was added. The sample was then vortexed vigorously and the absorbance read at $420 \mathrm{~nm}$ using a spectrophotometer (Cary 50 Bio UVVis; Varian Australia Pty Ltd., Victoria, Australia). Phosphate buffer saline was used as a blank and the measurement was carried out in duplicate. The concentration of free amino groups was calculated using the Beer-Lambert law, with an extinction coefficient $\varepsilon$ taken at 22,000 $\mathrm{M}^{-1} \mathrm{~cm}^{-1}$ (Adler-Nissen, 1979).

\section{Electrophoresis}

Reducing sodium dodecyl sulfate PAGE (SDS-PAGE) was used to study the protein and peptide patterns of MFGM materials and their enzymatically digested products.
Type of Gels. Precast NuPAGE Novex Bis-Tris 4 to $12 \%$ gels from Invitrogen (Merelbeke, Belgium) were used to separate proteins. For separation of polypeptides, derived after enzymatic digestion, Tris-tricine $15 \%$ gels were manually set in the laboratory using chemicals and materials from Bio-Rad SA/NV (Nazareth Eke, Belgium).

Sample Preparation. Sample preparation and reduction was similar for both types of gels. Ready-touse reagents such as NuPAGE lithium dodecyl sulfate (LDS) sample buffer and NuPAGE reducing agents from Invitrogen were used according to the protocol of the supplier. The sample preparation before loading on the gel was different for the whole MFGM sample compared with its digested products. The presence of lipids in the whole MFGM samples caused vertical streaks on the gel, which could only be avoided if these samples were partially defatted before reducing and loading on the gel. Defatting was performed by adding $40 \mu \mathrm{L}$ of diluted sample to $40 \mu \mathrm{L}$ methanol and $300 \mu \mathrm{L}$ of hexane in an Eppendorf tube, followed by repeated vortexing for $20 \mathrm{~s}$. The suspension was centrifuged at 2,040 $\times g$ for $30 \mathrm{~s}$ and the hexane (upper layer) was removed. Washing with $300 \mu \mathrm{L}$ of hexane was repeated twice more. The sample was then flushed with nitrogen gas until dry and redissolved in $40 \mu \mathrm{L}$ of deionized water under sonication. The load on each gel lane was $24 \mu \mathrm{g}$ of total protein (based on starting material) for Bis-Tris gels and $32 \mu \mathrm{g}$ for Tris-tricine gels. An additional lane was used to load the MW reference marker (Precision Plus Protein Standards; Bio-Rad SA/NV).

Running the Gels. Bis-Tris gels were run on an XCell SureLock system (Invitrogen) with cathode and anode buffers prepared from NuPAGE 3-(N-morpholino)propanesulfonic acid (MOPS) running buffer and NuPAGE antioxidant according to the protocol of the producer. Tris-Tricine $15 \%$ gels were run on a MiniProtean electrophoresis system (Bio-Rad SA/NV) operating at a constant $100 \mathrm{~V}$ for $1 \mathrm{~h}$.

Staining and Scanning of the Gels. Coomassie brilliant blue (CBB) and PAS staining were carried out to visualize protein bands after electrophoresis. Coomassie brilliant blue nonspecifically stains all proteins, whereas PAS staining is specific for detection of glycoproteins. The CBB staining was carried out using SimplyBlue SafeStain (Invitrogen) according to the supplier's procedure. Bis-Tris gels, after CBB staining and scanning to obtain the images, could be destained completely before PAS staining, which was applied to visualize the glycoproteins. Before staining Tris-Tricine $15 \%$ gels, a destaining/fixing step (Judd, 2002) was carried out to remove the background color before applying CBB or PAS staining. For this type of gels, it 
was difficult to remove the color completely after CBB staining. In this case, gels for $\mathrm{CBB}$ and PAS staining were made separately. After staining with $\mathrm{CBB}$ or PAS, the wet gels were scanned using a high-resolution transmission scanner (UMAX PowerLook III; UMAX Data Systems Inc., Taipei, Taiwan) and the gel was analyzed with ImageMaster TotalLab software (GE Healthcare, Diegem, Belgium).

\section{Enzymatic Digestion Experiments}

Digestion experiments were mainly applied to whole MFGM and lipid-free membrane protein mixtures. However, skim milk proteins were also included for comparison.

Gastric Digestion. The gastric or peptic digestion was carried out following the procedure of Vermeirssen et al. (2003). Hydrochloric acid (25\%) was used to bring deionized water to $\mathrm{pH}$ 2.0, MFGM materials were added, and the mixture was shaken in combination with sonication for $10 \mathrm{~min}$. The MFGM solution was readjusted to $\mathrm{pH} 2.0$ by $1 \mathrm{~N} \mathrm{HCl}$ and the final concentration was set to $4 \mathrm{~g}$ of total protein $/ 100 \mathrm{~mL}$. Pepsin was then added to an enzyme/substrate ratio of $1 / 250$ (wt/wt). The mixture was incubated at $37^{\circ} \mathrm{C}$ in a shaking temperature-controlled water bath. Samples were taken before addition of the enzyme, after 1-min incubation, and then every $20 \mathrm{~min}$, for a total digestion time of $3 \mathrm{~h}$. Immediately after sampling, samples were brought to $\mathrm{pH} 7.4$ by $1 \mathrm{~N} \mathrm{NaOH}$ to inactivate the pepsin activity. The effect of dilution due to $\mathrm{pH}$ adjustment was taken into account in the further analyses. The samples were analyzed for free amino groups and placed in a freezer $\left(-40^{\circ} \mathrm{C}\right)$ for later analysis.

\section{Gastrointestinal Digestion}

Digestion with Pepsin, Trypsin, and $\alpha$-Chymotrypsin $(\boldsymbol{P T C})$. Trypsin and $\alpha$-chymotrypsin are 2 main enzymes hydrolyzing peptides and proteins in the small intestine. After $2 \mathrm{~h}$ of incubation with pepsin as described above, the sample was brought to $\mathrm{pH} 6.5$ using $\mathrm{NaOH}(1 \mathrm{~N})$. Both trypsin and $\alpha$-chymotrypsin were added at a concentration of $1 \mathrm{~g}$ of each enzyme/250 $\mathrm{g}$ of total protein. The mixture was vortexed and then incubated under continuous shaking at a temperature of $37^{\circ} \mathrm{C}$. Samples were taken before addition of pepsin, after 2-h treatment with pepsin, and after additional incubation for 2.5 and $3.5 \mathrm{~h}$ with trypsin and $\alpha$-chymotrypsin. After sampling, samples were heated at $80^{\circ} \mathrm{C}$ for $10 \mathrm{~min}$ to inactivate the enzymes. Then, they were loaded on the gels to evaluate the degree of hydrolysis.
Digestion with Pepsin and Simulated Pancreatic Juice. Pancreatic juice contains not only the 2 main proteases trypsin and $\alpha$-chymotrypsin but also other enzymes such as lipases and phospholipases, which can hydrolyze triacylglycerides and phospholipids present in the MFGM. In this experiment, whole MFGM was treated with pepsin in combination with simulated pancreatic juice (PSP). The simulated pancreatic juice was prepared by dissolving $4.5 \mathrm{~g}$ of pancreatin, $62.5 \mathrm{~g}$ of $\mathrm{NaHCO}_{3}$, and $30 \mathrm{~g}$ of bile salts (Sigma, Auckland, New Zealand) in $1 \mathrm{~L}$ of deionized water (Van de Wiele et al., 2004). This experiment was performed to elucidate whether the lipids [due to their structure in the form of lipid packing (Gallier et al., 2012) in the MFGM] protect the MFGM proteins against digestion by proteases. This experiment was carried out in a similar manner as described above, with the exception of the mixture of trypsin and $\alpha$-chymotrypsin, which was replaced by pancreatin juice at a ratio of $1: 10$ (vol/ vol) to the MFGM solution.

\section{Dialysis}

In this experiment, a dialysis process using membrane tubes with 3 different MW cut-off values, namely 0.5 , 1.0 , and $3.5 \mathrm{kDa}$, obtained from Spectra/Por (VWR, Leuven, Belgium), was used to remove AA and small peptides from the hydrolyzed solutions. Samples were withdrawn after 2-h peptic treatment plus 2.5-h digestion with trypsin and $\alpha$-chymotrypsin or PSP and were then dialyzed under gentle shaking against 3 exchanges of deionized water at $4^{\circ} \mathrm{C}$. For each exchange, the volume of deionized water was 100 times higher than that of the samples. The first 2 exchanges were performed for $4 \mathrm{~h}$, whereas the last one was left overnight at $4^{\circ} \mathrm{C}$ in the refrigerator. The retentates (remaining samples inside the tubes) were kept for analysis. The increase in volume during dialysis was taken into account for the analyses. The absorbance of the dialysates (solutions outside of the tubes) measured at $214 \mathrm{~nm}$ was also used as an indicator to evaluate the permeation of $\mathrm{AA}$ and small peptides through the membranes.

\section{Identification of Proteins}

The original MFGM proteins on SDS-PAGE were identified based on their MW, separation order, and response to $\mathrm{CBB}$ and PAS staining. Based on these characteristics, MFGM proteins were named according to Mather (2000). For identification of proteins that resisted the enzymatic digestions, a mass spectrometric approach was employed. Briefly, protein bands were cut from the SDS-PAGE gels followed by an in-gel diges- 
tion with trypsin and a peptide extraction, as described previously (Vanrobaeys et al., 2005). The peptide extractions were dried and were dissolved in $12 \mu \mathrm{L}$ of $2 \%$ ( vol $/ \mathrm{vol}$ ) acetonitrile, $0.1 \%$ (vol/vol) formic acid in water before analysis using an Applied Biosystems 4800+ Proteomics Analyzer with time-of-flight (TOF/TOF) optics (Applied Biosystems Inc., Foster City, CA); $0.6 \mu \mathrm{L}$ of the sample was applied to a stainless steel 384-well target plate, followed by addition of $0.6 \mu \mathrm{L}$

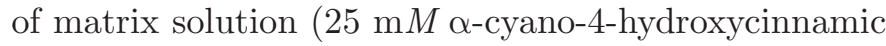
acid $+10 \mathrm{~m} M$ ammonium citrate solution in $50 \%$ acetonitrile containing $0.1 \%$ trifluoroacetic acid). The matrix-assisted laser desorption ionization (MALDI)spectra were searched using GPS-explorer (v3.6; Applied Biosystems Inc.) against the Swiss-Prot Bos taurus database (http://www.uniprot.org/uniprot; 200 $\mathrm{mg} / \mathrm{kg}$ and $0.8 \mathrm{Da})$.

\section{Statistical Analysis}

All experiments were repeated 3 times on different days. Average values were graphed and standard deviation values were also indicated. One-way ANOVA tests were carried out using the S-Plus 8.0 package for Windows (Tibco Software Inc., Palo Alto, CA) to find differences $(P \leq 0.05)$ among samples.

\section{RESULTS AND DISCUSSION}

\section{Gastric Digestion}

Gastric Digestion of Lipid-Free Protein Mixture Obtained from Defatting Whole MFGM Material. The SDS-PAGE pattern of the lipid-free protein mixture obtained from defatting whole MFGM material was characterized by a complex protein profile containing many protein bands in a wide range of molecular weights (Figure 1A and B, lane 3). Many protein bands of the MFGM sample were still observed after PAS staining. These are all glycoproteins such as MUC1, PAS III, CD36, BTN, and PAS 6/7, which are the major MFGM proteins.

Based on the CBB-stained gel, it was found that almost all stained proteins of the lipid-free protein mixture derived from MFGM material were hydrolyzed by pepsin after 20 min of digestion (Figure 1A). Without addition of pepsin, no significant hydrolysis of the membrane proteins was observed after 2 -h incubation at $\mathrm{pH} 2.0$ (results not shown). Therefore, it could be concluded that the hydrolysis was the result of pepsin activity and was not caused by high acidity. The fast rate of hydrolysis was confirmed by measuring the concentration of free amino groups (Figure 2). About
$40 \%$ of the increase in free amino groups during $3 \mathrm{~h}$ of digestion occurred during the first $20 \mathrm{~min}$ of hydrolysis.

The PAS-stained gel indicated that the major part of MUC1 resisted against the action of pepsin (Figure 1B). Mucin 1 could only slightly be seen when stained by $\mathrm{CBB}$ staining (Figure 1A and $\mathrm{C}$ ), but was clearly visualized by PAS staining (Figure $1 \mathrm{~B}$ and $\mathrm{D}$ ). The resolution of MUC1 into 2 bands on SDS-PAGE was reported earlier by Patton and Patton (1990) and was also genetically confirmed as 2 allelic variants, $\mathrm{D}$ and G, respectively, by Sando et al. (2009). Based on the PAS-stained gel, considerable parts of both variants of MUC1 were non-cleaved after $3 \mathrm{~h}$ of gastric digestion. Besides MUC1, the CD36 band remained visible, suggesting this protein was not completely hydrolyzed. A faint band was still observed at the original MW of PAS III (Figure 1B).

Gastric Digestion of Whole MFGM. The trend of digestion of the whole MFGM, based on the release of amino groups, was similar to that of the lipid-free protein mixture obtained from defatting whole MFGM material (Figure 2). Based on SDS-PAGE analysis, the most obvious difference compared with gastric digestion of the lipid-free protein mixture was the remaining bands corresponding to PAS $6 / 7$ and ADPH. In 1-dimensional SDS-PAGE, ADPH and PAS 6/7 normally co-migrate, as they have similar MW (Heid et al., 1996). Adipophilin does not stain with Schiff reagents (Mather, 2000), but in our experiment, 2 bands were visualized in the PAS stained gel (lane 6-14, Figure 1D). These bands were subjected to mass spectrometric identification. Most of the prominent peaks in the MALDI spectra obtained from tryptic digest mixture corresponded with PAS 6/7, whereas none of them were assigned to ADPH. As such, the presence of PAS $6 / 7$ in the double bands was confirmed.

For the whole MFGM sample after $2 \mathrm{~h}$ of digestion with pepsin, mass spectrometric analysis showed the presence of $\mathrm{XDH} / \mathrm{XO}$ in both bands of MUC1. Even more peptides of $\mathrm{XDH} / \mathrm{XO}$ were hereby detected compared with those of MUC1. However, this does not necessarily mean that concentrations of XO and BTN in these fractions were higher than that of MUC1. It may be possible that MUC1 (after SDS-PAGE) was still resistant to trypsin digestion before MS analysis. As mentioned in the introduction, MUC1 from human milk is very resistant to gastric and intestinal digestion (Patton, 1994; Hamosh et al., 1999).

A faint band of BTN at its original MW was still observed until 60 min of peptic digestion using CBB. Peterson et al. (1998) reported that about 37\% of MUC1 and 25\% of PAS 6/7 remained intact in gastric aspirates of breast milk-fed infants after 4-h incubation, 


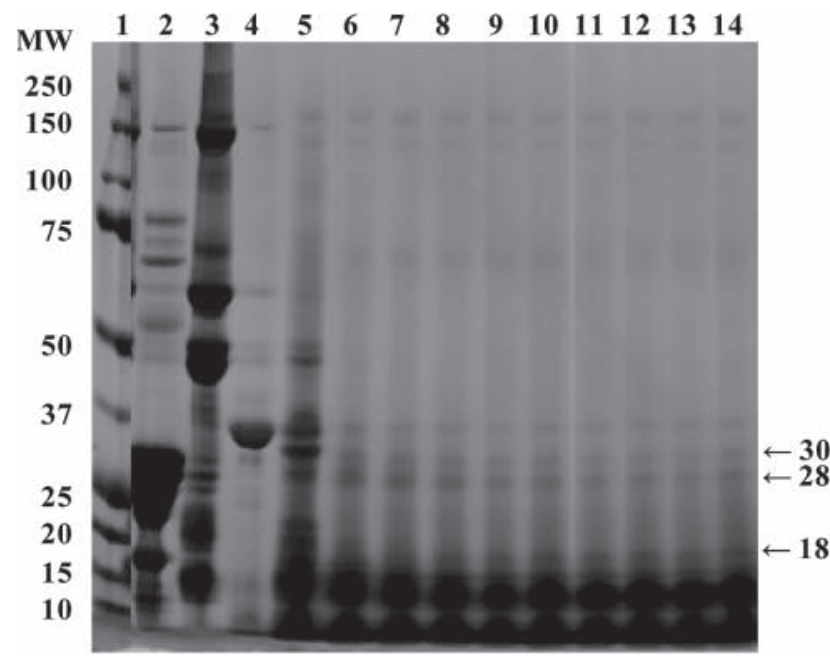

A

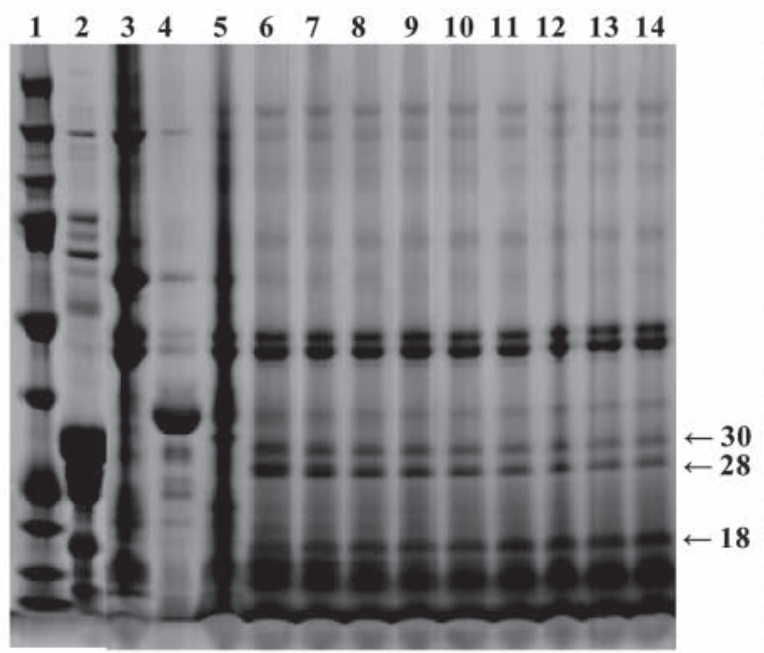

C
3

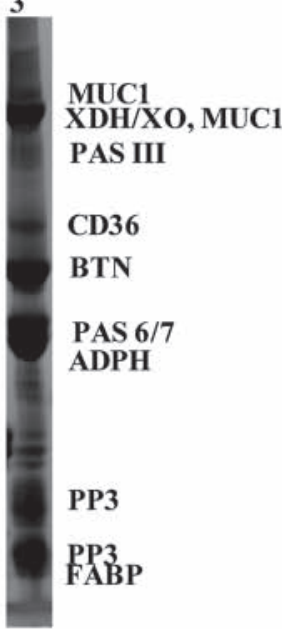

2

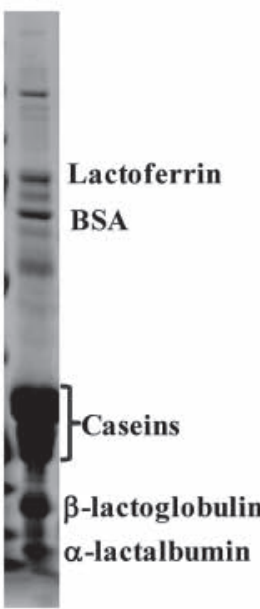

$\begin{array}{llllllllllllllll}1 & 2 & 3 & 4 & 5 & 6 & 7 & 8 & 9 & 10 & 11 & 12 & 13 & 14\end{array}$

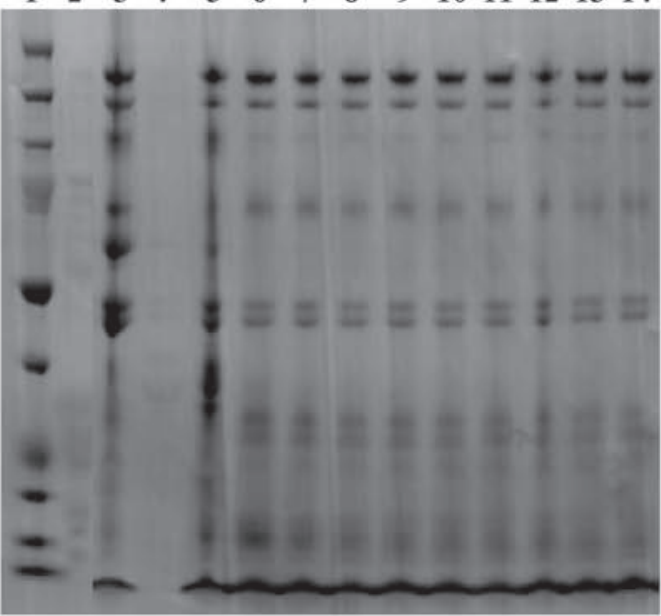

D

Figure 1. Changes in polypeptide patterns of the lipid-free protein mixture obtained from defatting whole milk fat globule membrane (MFGM) material (A and B) and whole MFGM (C and D) during digestion with pepsin as seen by SDS-PAGE separation using 4 to $12 \%$ BisTris gels. A and C were stained with Coomassie blue and B and D with periodic acid Schiff (PAS) reagents after removal of Coomassie blue. In all gels, lane 1 was loaded with molecular weight (MW) standard, of which markers (in $\mathrm{kDa}$ ) are indicated to the left of gel A; lane 2 was loaded with skim milk; lane 3 was loaded with non-digested lipid-free membrane protein mixture (A and B) or non-digested whole MFGM (C and D); lane 4 was loaded with pepsin $(6 \mu \mathrm{g})$; and lanes 5 to 14 were samples digested with pepsin for $1,20,40,60,80,100,120,140,160$, and 180 min, respectively. A copy of lane 3 from gel A is shown separately to indicate better the major MFGM proteins. MUC1 = mucin 1, XDH/ $\mathrm{XO}=$ xanthine dehydrogenase/oxidase, PAS III = periodic acid Schiff III, CD36 = cluster of differentiation 36, BTN = butyrophilin, PAS $6 / 7$ $=$ periodic acid Schiff $6 / 7, \mathrm{ADPH}=$ adipophilin, PP3 = proteose peptone $3, \mathrm{FABP}=\mathrm{FA}$-binding protein. $\mathrm{A}$ copy of lane 2 from gel $\mathrm{C}$ is shown separately to indicate better the major skim milk proteins. Arrows point to polypeptide bands and the numbers of the arrows indicate the MW.

whereas virtually all BTN was broken down. This is quite in accordance with the observation in the current study.

The resistance of MUC1 and PAS 6/7 upon peptic digestion of both washed fat globules and isolated MFGM fragments was also reported in the work of Shimizu et al. (1979). Recently, Ye et al. (2011) did not observe the resistance of PAS 6/7 after treatment of raw milk with simulated gastric fluid. In their investi- gation, raw milk was treated and the fat globules were washed and loaded on SDS-PAGE. It was expected that the fat globules were in native/intact form when they were subjected to pepsin. However, damage of the fat globule surface during the digestion, under low $\mathrm{pH}$ in combination with continuous agitation, cannot be ruled out. Periodic acid Schiff $6 / 7$ is a peripheral protein of MFGM, which interacts loosely with the latter and is subject to loss during washing of cream (Mather 


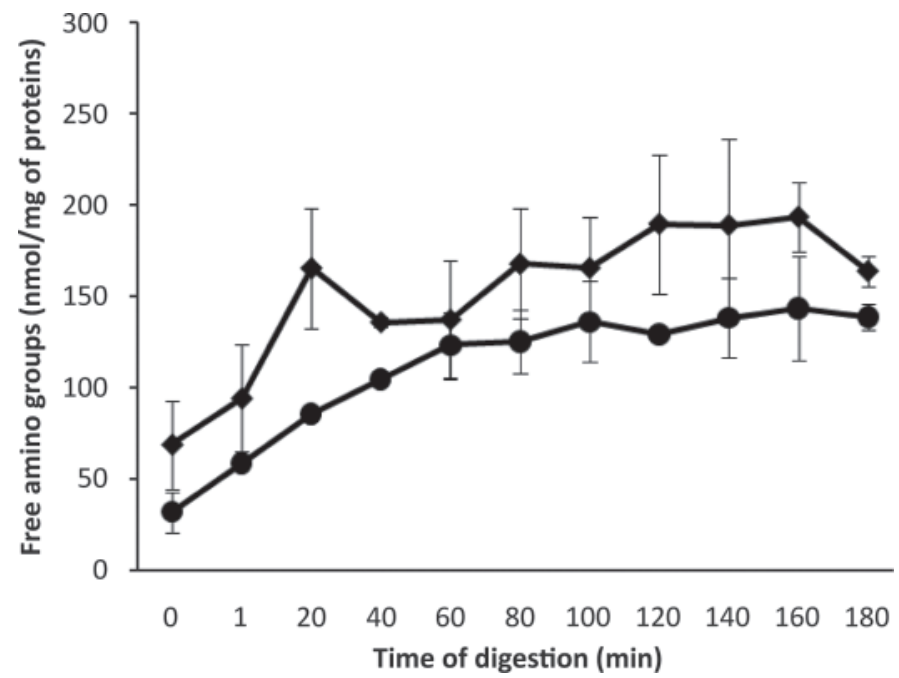

Figure 2. Changes in the amounts of free amino groups during peptic digestion of whole milk fat globule membrane (MFGM; $\bullet$ ) and lipid-free membrane protein mixture $(\bullet)$. Error bars correspond to standard deviations of 3 replicates.

and Keenan, 1975). After peptic treatment of the fat globules, their repulsion among each other is supposed to change as well due to the change in protein composition on the surface. A decrease in repulsion of fat globules would increase the damage of the fat globule surface due to an increase in collision and coalescence of the denuded fat globules during centrifugation and resuspension. Washing of the cream may cause part of the bilayer to shred from the globules (Vanderghem et al., 2011). These points indicate that caution should be taken when comparing the result of Ye et al. (2011) with the results in our study.

After $3 \mathrm{~h}$ of incubation of whole MFGM with pepsin, bands of PAS III and CD36 could still be observed at their original MWs of $100-110$ and $70 \mathrm{kDa}$ as in the case of digestion of the lipid-free samples. A band of which the molecular weight corresponded best to CD36 was observed after $2 \mathrm{~h}$ of digestion. However, no significant MALDI fingerprint of this band was obtained. It may be assumed that the remaining protein in this band was resistant to the in-gel digestion with trypsin or that its concentration was too low to be detected.

Other Observations for Both Types of MFGM Materials. For both types of materials, the lipid-free membrane protein mixture and whole MFGM, XDH/ XO, BTN, and PP3 (e.g., first band) were easily hydrolyzed by pepsin. The results obtained might indicate that more heavily glycosylated proteins show higher resistance toward peptic digestion. Pepsin does not hydrolyze the linkages between the carbohydrate groups and polypeptides and these groups probably hamper the activity of the enzyme. In addition, it may be con- cluded that the lipid fraction in MFGM played a role in protecting some MFGM proteins against the action of pepsin. Glycolipids, although present in low amounts, may also provide a shielding effect via formation of a glycocalyx with glycoproteins. As mentioned, PAS 6/7 is believed to be a peripheral component of MFGM with a small part of the polypeptide embedded in the bilayer (Mather and Keenan, 1975; Mather, 2000). The other side of the molecule is expected to be subjective to pepsin attack. Irrespective of that fact, the resistance of PAS 6/7 was high. It was probable that the molecule regions that are naturally not embedded into the phospholipid bilayer were somehow in interaction with another shred bilayer patch (detached piece of bilayer), making them inaccessible to pepsin. The PAS $6 / 7$ of a membrane fragment or a shred patch of bilayer could interact with the neutral triglyceride side (e.g., the triglycerides were shred along with the membrane out of the core fat during churning) of neighboring membrane fragments as well. Periodic acid Schiff $6 / 7$ displayed a higher affinity toward the total lipid fraction derived from MFGM as compared with pure phospholipids (Andersen et al., 1997).

Below $15 \mathrm{kDa}$, several intense and broad bands of peptides can be seen. Many of these peptides are stained by PAS, indicating that these peptides still carry carbohydrate groups. To obtain a better separation, electrophoresis with Tris-tricine 15\% gels was carried out (Figure 3). As expected, many small peptides were found, whereas the separation of the native MFGM proteins became less efficient (Figure 3, lane 1). The SDS-PAGE patterns between 2 types of staining were not the same. Bands were observed after CBB but not after PAS staining and vice versa. Peptide bands on PAS-stained gels were broader compared with CBBstained gels. For whole MFGM samples, a similar observation during digestion could be seen as in the case of the lipid-free protein mixture (figure not shown).

\section{Gastrointestinal Digestion}

Digestion with PTC. With the lipid-free protein mixture, and after further digestion for $2.5 \mathrm{~h}$ with trypsin and $\alpha$-chymotrypsin, the remaining PAS III and CD36 were hydrolyzed into shorter peptides, whereas the major part of MUC1 that was not digested by pepsin still resisted the activity of these 2 intestinal proteases (Figure 4, lanes 5-8).

The peptide profiles for whole MFGM, which had been digested by the same digestion procedure, are shown in Figure 5 (lanes 5-8). The 2 bands at original MW of PAS 6/7 (at 48 and $46 \mathrm{kDa}$ ), which survived the pepsin activity, became 2 less-intense bands at 46 and $43 \mathrm{kDa}$ after further digestion with trypsin and 

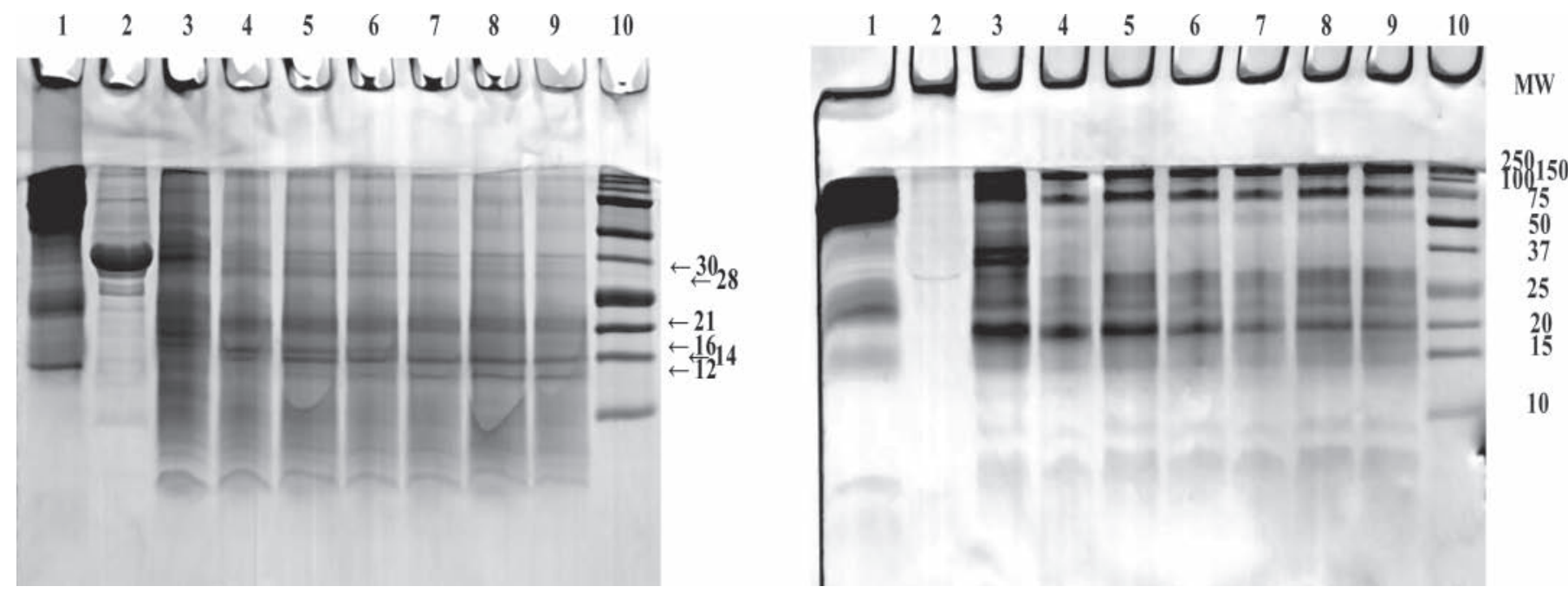

Figure 3. Polypeptide patterns of pepsin-digested lipid-free membrane protein mixture on Tris-tricine $15 \%$ gels stained by Coomassie brilliant blue (CBB; left) and periodic acid Schiff (PAS; right). Lane $1=$ lipid-free membrane protein mixture; lane $2=$ pepsin; lanes 3 to $9=$ lipidfree membrane protein mixture digested by pepsin for 1, 20,40,60, 80, 100, and 120 min, respectively; lane $10=$ Bio-Rad SA/NV (Nazareth Eke, Belgium) molecular weight (MW) marker. Arrows point to peptide bands.

Q-chymotrypsin. The slight decrease in MW (an extent of several $\mathrm{kDa}$ ) could indicate a limited cleavage at one terminal of the protein molecules (probably the terminal that is not embedded in the phospholipid bilayer). The change in $\mathrm{pH}$ from the gastric condition to intestinal condition may change the interaction of

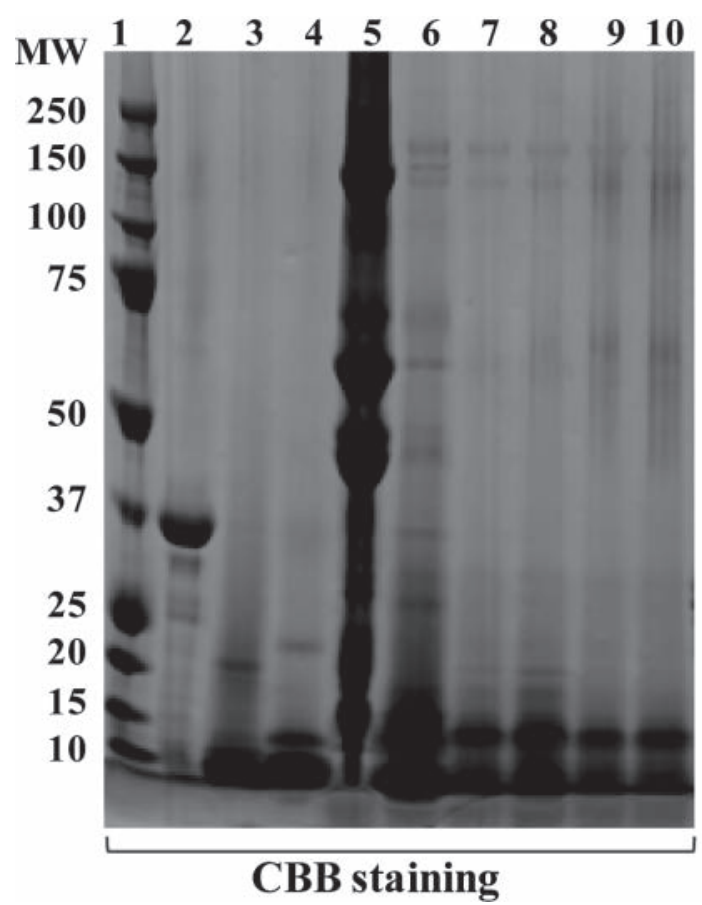

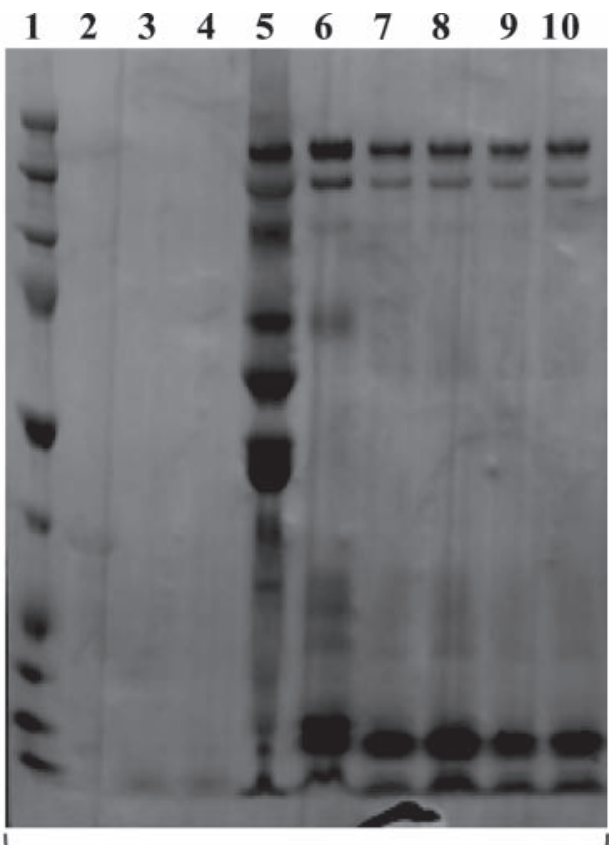

PAS staining

Figure 4. Polypeptide patterns of lipid-free membrane protein mixture during digestion with gastrointestinal proteases. Separation was performed with SDS-PAGE using 4 to 12\% Bis-Tris gels and stained by Coomassie brilliant blue (CBB; left) and periodic acid Schiff (PAS; right). Lane $1=$ molecular markers (in $\mathrm{kDa}$ ), which are indicated on the left; lanes 2 to 4 = pepsin, trypsin, and $\alpha$-chymotrypsin, respectively; lane 5 $=$ non-digested lipid-free membrane protein mixture; lane $6=$ lipid-free membrane proteins treated by pepsin for $2 \mathrm{~h}$; lanes 7 and $8=$ lipid-free membrane proteins treated further by trypsin and $\alpha$-chymotrypsin for 2.5 and $3.5 \mathrm{~h}$, respectively; lanes 9 and $10=$ samples as in lane 7 after being dialyzed with $0.5-$ and $3.5-\mathrm{kDa}$ membranes, respectively. The identification of proteins is given in Figure 1. 

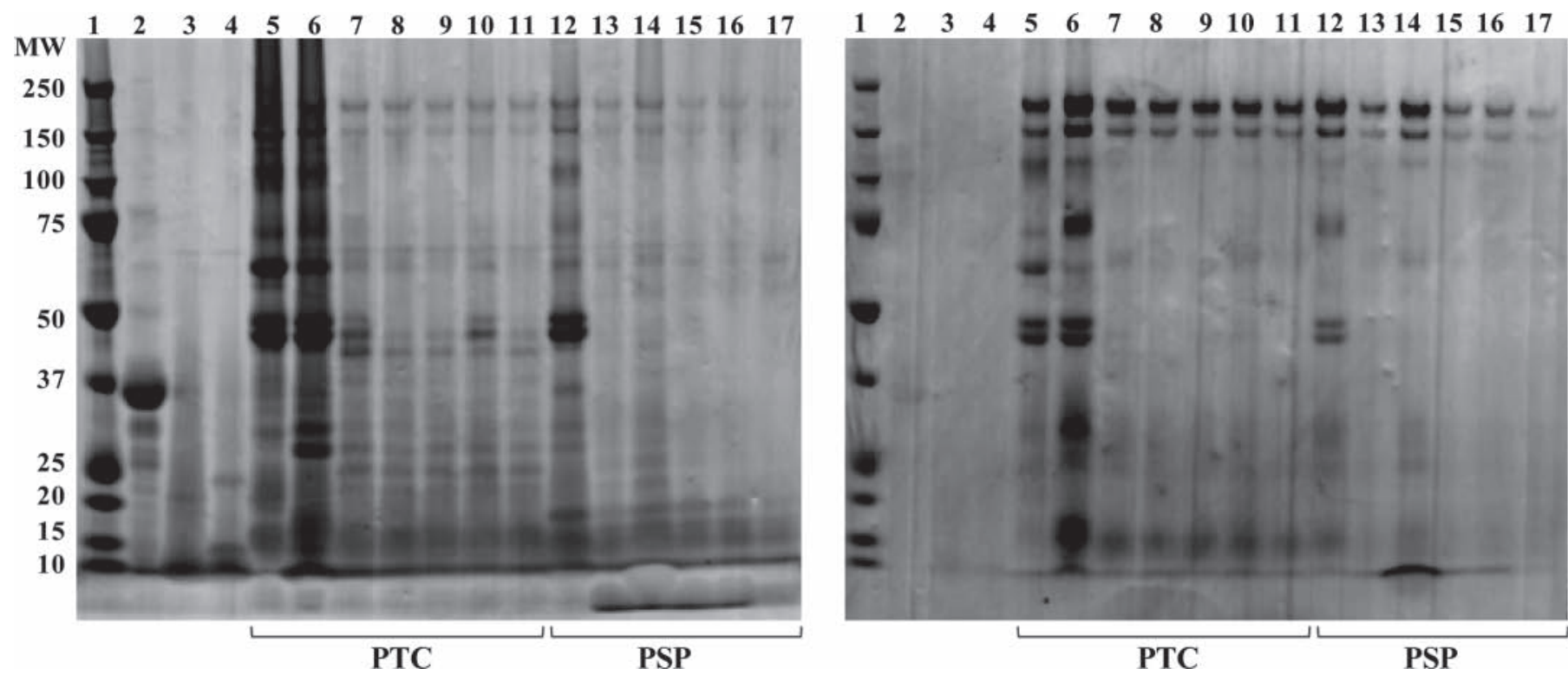

Figure 5. Polypeptide patterns of whole milk fat globule membrane (MFGM) during digestion with pepsin followed by trypsin and $\alpha$-chymotrypsin (PTC) and during digestion with pepsin, followed by simulated pancreatic juice (PSP). Separation was performed on 4 to $12 \%$ Bis-Tris gels and stained by Coomassie brilliant blue (CBB; left) and periodic acid Schiff (PAS; right). Lane $1=$ molecular markers (in $\mathrm{kDa}$ ), which are indicated on the left; lanes 2 to 4 = pepsin, trypsin, and $\alpha$-chymotrypsin, respectively; lane $5=$ native whole MFGM; lane $6=$ whole MFGM treated by pepsin for $2 \mathrm{~h}$; lanes 7 and $8=$ whole MFGM treated further by trypsin and $\alpha$-chymotrypsin for 2.5 and 3.5 h, respectively; lanes 9,10 , and $11=$ samples as in lane 7 after being dialyzed with $0.5-, 1.0-$, and $3.5-\mathrm{kDa}$ membranes, respectively; lanes 12 to $17=$ whole MFGM after hydrolysis under similar conditions as in lanes 6 to 11, except that a combination of simulated pancreatic juice and bile salts was used instead of a mixture of trypsin and $\alpha$-chymotrypsin. Identification of proteins is identical to those in Figure $1 .$.

PAS 6/7 with other components, which makes it accessible to trypsin and chymotrypsin. The major part of MUC1 that remained intact after peptic digestion was not hydrolyzed after further digestion with trypsin and $\alpha$-chymotrypsin. Also, for whole MFGM samples, the peptide bands at 30 and $28 \mathrm{kDa}$ remained visible, whereas these disappeared for the lipid-free protein mixture samples. This illustrates that the original MFGM structure containing the lipid fraction had a protecting effect on the hydrolysis of the MFGM proteins embedded in the membrane.

The increase in amount of free amino groups during digestion with the 2 samples in this experiment is presented in Figure 6. Similar profiles were observed for the 2 materials. No significant difference was found. However, the variation among the repeats of the experiment was quite high.

Digestion of Whole MFGM with PSP. The SDSPAGE profiles of whole MFGM after digestion with PTC and PSP are illustrated in Figure 5. A difference between PTC and PSP treatments on whole MFGM material was found (lanes 7-8 and lanes 13-14). Periodic acid Schiff $6 / 7$ and the peptide bands at 30 and 28 $\mathrm{kDa}$ were not observed anymore after PSP treatment. During PSP treatment, lipases and phospholipases present in the mixture will hydrolyze the lipid fraction, thereby increasing the vulnerability of some MFGM

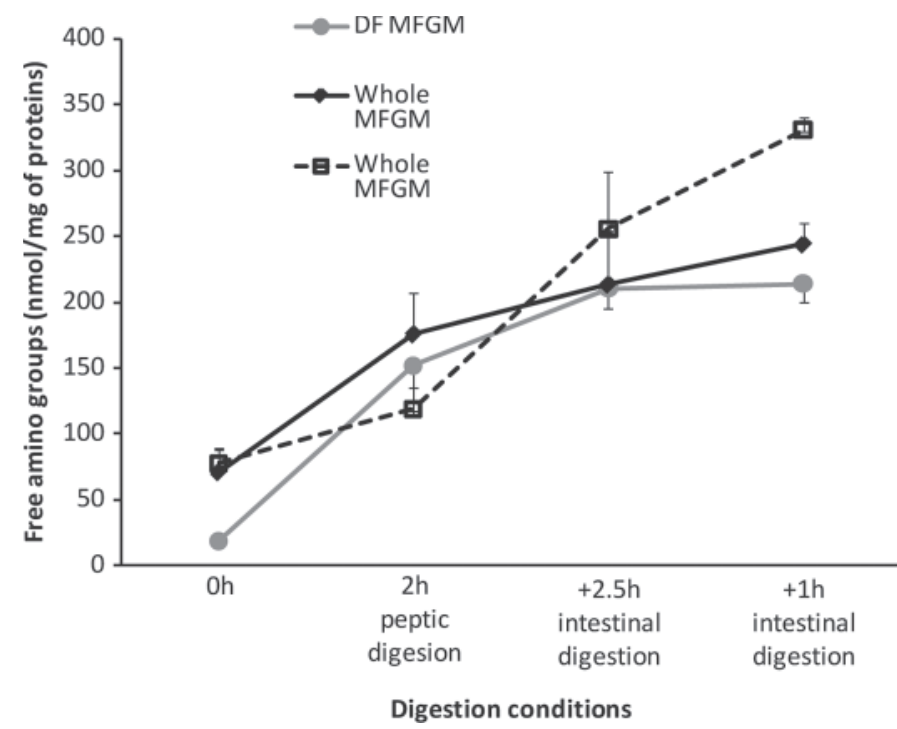

Figure 6. Changes in amount of free amino groups during digestion of lipid-free membrane proteins $(\bullet)$ and whole milk fat globule membrane (MFGM; $\bullet$ ) for $2 \mathrm{~h}$ with pepsin and then further for 2.5 and $3.5 \mathrm{~h}$ with a combination of trypsin and $\alpha$-chymotrypsin. The further digestion with simulated pancreatic juice instead of the 2 intestinal proteases was also carried out for the whole MFGM ( $\square$ ) sample. Error bars show half standard deviations of 3 replicates. DF MFGM = defatted MFGM or lipid-free membrane protein mixture. 
proteins toward attack by proteases (e.g., trypsin and $\alpha$-chymotrypsin). Bile salts are amphiphilic molecules that form micelles with the MFGM lipids, thereby rendering them more hydrophilic for the action of lipases (Watkins, 1985).

Following the time course of digestion, the increase of free amino groups during digestion showed a higher hydrolysis during PSP treatment compared with PTC treatment (Figure 6). After $5.5 \mathrm{~h}$ (i.e., $3.5 \mathrm{~h}$ after adding the simulated pancreatic juice or trypsin in combination with $\alpha$-chymotrypsin), the amount of free amino groups of PSP-digested whole MFGM was significantly higher than that of the same material digested with a mixture of trypsin and $\alpha$-chymotrypsin. This observation confirmed the difference on SDS-PAGE patterns found in Figure 5 as discussed previously. After PTC digestion of the lipid-free protein mixture obtained from defatting whole MFGM material and PSP digestion of the latter, the bands associated with MUC1 were investigated by MS analysis but no specific MUC1 peptides were detected. As indicated earlier, it might be possible that this remaining fraction of MUC1 was still resistant to the activity of trypsin, even though the protein was already denatured during the SDS-PAGE process. The resistance of the protein core to proteolytic cleavage of densely $O$-glycosylated proteins is a challenge in proteomic analysis using mass spectrometric identification (Hanisch et al., 2001). Using immunostaining, Patton detected 200-kDa fragments of MUC1 in 3 of 7 stool specimens from breast-fed babies, whereas the protein was not detected in 7 other samples from formula-fed babies (Patton, 1994). By the mass spectrometric analysis, some peptides from PAS $6 / 7$ were detected in the range of 25 to $15 \mathrm{kDa}$ after digestion of the lipidfree membrane protein mixture with PTC (Figure 4B, lane 8).

\section{Dialysis of the Digested MFGM Products}

Dialysis can be used as a simulation model for the absorption process in the small intestine (Gatellier and Santé-Lhoutellier, 2009). Free AA and small peptides (di- or tripeptides) are absorbed by the lining of the small intestine. The amount of free amino groups in the retentates is shown in Figure 7. As expected, the higher the MW cut-off of the membranes, the lower the amounts of free amino groups in the solutions retained. This was in accordance with the UV absorbance at 214 $\mathrm{nm}$ of the dialysates, which means the larger the pore sizes, the higher the absorbance of the dialysates (results not shown). When the PTC and PSP treatments on whole MFGM were compared, no clear difference on the amounts of free amino groups in the retained solutions was detected with the $0.5-$ and $1.0-\mathrm{kDa}$ mem-

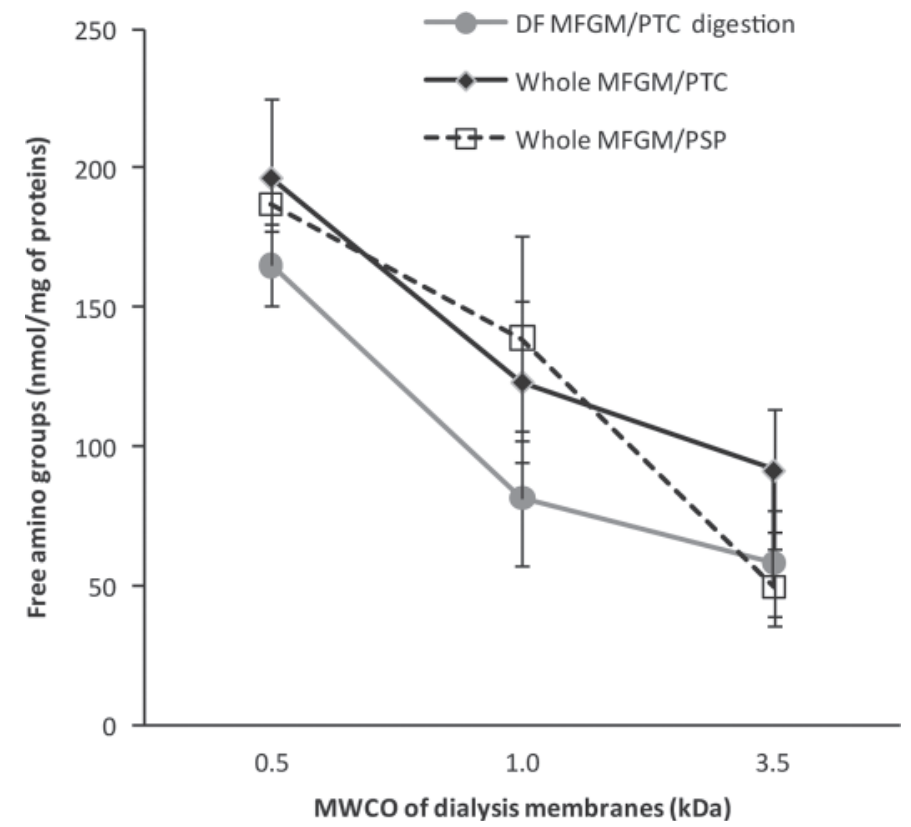

Figure 7. Concentration of amino groups of the digested solutions retained inside the dialysis bags with different membrane pore sizes. Lipid-free protein mixture $(\bullet)$ and whole milk fat globule membrane (MFGM; ) were digested for $2 \mathrm{~h}$ with pepsin and further for 2.5 $\mathrm{h}$ with a combination of trypsin and $\alpha$-chymotrypsin before dialysis. Further digestion with simulated pancreatic juice instead of the 2 intestinal proteases was also carried out for whole MFGM ( $\square$ ) before dialysis. Error bars show half standard deviations of 3 replicates. MWCO = molecular weight cut-off; PTC = digestion with pepsin, trypsin, and $\alpha$-chymotrypsin; DF MFGM $=$ defatted MFGM or lipidfree membrane protein mixture; $\mathrm{PSP}=$ pepsin and simulated pancreatic juice.

brane. However, with the $3.5-\mathrm{kDa}$ membrane, the PSPtreated whole MFGM retained fewer free amino groups compared with the PTC treatment. This indicates that during PSP treatment, the hydrolysis was more intensive. More small peptides were produced and these molecules can permeate through the $3.5-\mathrm{kDa}$ membrane. These results confirm the data indicated in Figure 6 as well as the SDS-PAGE patterns shown in Figure 5.

Because only very small peptides could permeate through the membranes, the SDS-PAGE patterns in Figure 4 and Figure 5 did not show any difference between the samples before and after dialysis. For example, peptides with less than 3 or 4 AA can migrate through the $1.0-\mathrm{kDa}$ membrane. It might be possible that part of MUC1 can be transferred intact into the colon. Many peptides as well could have the chance to be in the colon, with many of them still containing carbohydrates. Even when PSP treatment was applied, broad bands of peptides were observed with both CBB and PAS staining. Pancreatin contains enzymes that can hydrolyze common carbohydrates (for example, amylases); however, these enzymes probably did not 
cut the links between carbohydrates and proteins in glycoproteins. Indeed, glycoproteins are substrates for hydrogen and methane production by colonic bacteria from healthy adults. The hydrogen production is attributed to carbohydrate fermentation (Perman and Modler, 1982).

Milk fat globule membrane-enriched materials isolated from industrial buttermilk or butter serum normally contain high levels of milk serum proteins, such as caseins and whey proteins (Corredig et al., 2003; Le et al., 2011). Enzymatic treatments may be applied to remove these non-MFGM proteins, as they were easily digested by gastrointestinal enzymes (results not shown). In addition, the results of the current study also point out the possibilities of producing MFGM protein mixtures that are enriched in potential beneficial glycopolypeptides. These mixtures are promising for testing the antiviral properties and anti-adhesion of pathogens because they contain a proportion of MFGM glycosylated polypeptides, which are resistant to human gastrointestinal digestion. However, all of these perspectives need to be investigated more thoroughly in the future. The current impediment to application of purified membrane glycoproteins as nutraceuticals is the high cost related to isolation and purification of these proteins.

\section{CONCLUSIONS}

For both types of MFGM materials, namely whole MFGM and lipid-free membrane protein mixtures, a significant part of MUC1, the most heavily glycosylated MFGM protein, remained intact under the action of pepsin and a combination of trypsin and $\alpha$-chymotrypsin. For peptic digestion of the lipid-free membrane protein mixture, a minor part of PAS III and a considerable part of CD36 also maintained their integrity. However, these proteins were broken down when the material was further digested with trypsin and $\alpha$-chymotrypsin. When whole MFGM was used, a considerable part of PAS 6/7, in addition to MUC1, PAS III, and CD36, as in the case of the lipid-free protein mixture, was not cleaved by pepsin. A considerable part of this remaining PAS 6/7 is still resistant against hydrolysis with trypsin and chymotrypsin if the lipid moiety has not been hydrolyzed. When pancreatin, which also contains lipases and phospholipases, was used in combination with bile salts instead of trypsin and chymotrypsin, the peptic resistant part of PAS 6/7 was hydrolyzed. The determining factor that protects PAS 6/7 against proteolytic digestion is, therefore, related to the lipids of the MFGM. Two influencing factors that are important in increasing the stability of MFGM proteins against proteolysis during digestion are degree of glycosylation (in case of MUC1, PAS 3, and CD36) and the steric shielding effect of the lipids (in the case of PAS 6/7 and probably also BTN and $\mathrm{ADPH})$ against the action of pepsin.

\section{ACKNOWLEDGMENTS}

This study was financially supported by a Special Research Fund (BOF) scholarship of Ghent University (BOF07/DOS/047) and by the Fund for Scientific Research (FWO, Flanders, Belgium), project number G.0490.08.

\section{REFERENCES}

Adler-Nissen, J. 1979. Determination of the degree of hydrolysis of food protein hydrolysates by trinitrobenzenesulfonic acid. J. Agric. Food Chem. 27:1256-1262.

Andersen, M. H., L. Berglund, J. T. Rasmussen, and T. E. Petersen. 1997. Bovine pas- $6 / 7$ binds $\alpha_{\mathrm{v}} \beta_{5}$ integrin and anionic phospholipids through two domains. Biochemistry 36:5441-5446.

AOAC. 2006. Nitrogen (Total) in Milk-Kjeldahl Methods. Official Method 991.20. AOAC International, Gaithersburg, MD.

Bojsen, A., J. Buesa, R. Montava, A. S. Kvistgaard, M. B. Kongsbak, T. E. Petersen, C. W. Heegaard, and J. T. Rasmussen. 2007. Inhibitory activities of bovine macromolecular whey proteins on rotavirus infections in vitro and in vivo. J. Dairy Sci. 90:66-74.

Bu, H.-F., X.-L. Zuo, X. Wang, M. A. Ensslin, V. Koti, W. Hsueh, A. S. Raymond, B. D. Shur, and X.-D. Tan. 2007. Milk fat globuleEGF factor 8/lactadherin plays a crucial role in maintenance and repair of murine intestinal epithelium. J. Clin. Invest. 117:36733683.

Campagna, S., A.-G. Mathot, Y. Fleury, J. M. Girardet, and J. L. Gaillard. 2004. Antibacterial activity of lactophoricin, a synthetic 23-residues peptide derived from the sequence of bovine milk component-3 of proteose peptone. J. Dairy Sci. 87:1621-1626.

Catchpole, O. J., S. J. Tallon, J. B. Grey, K. Fletcher, and A. J. Fletcher. 2008. Extraction of lipids from a specialist dairy stream. J. Supercrit. Fluids 45:314-321.

Chandan, R. C., J. Cullen, B. D. Ladbrooke, and D. Chapman. 1971. Physicochemical analyses of bovine milk fat globule membrane. 1. Differential thermal analysis. J. Dairy Sci. 54:1744-1751.

Corredig, M., R. R. Roesch, and D. G. Dalgleish. 2003. Production of a novel ingredient from buttermilk. J. Dairy Sci. 86:2744-2750.

Dewettinck, K., R. Rombaut, N. Thienpont, T. T. Le, K. Messens, and J. V. Camp. 2008. Nutritional and technological aspects of milk fat globule membrane material. Int. Dairy J. 18:436-457.

Fong, B. Y., C. S. Norris, and A. K. H. MacGibbon. 2007. Protein and lipid composition of bovine milk-fat-globule membrane. Int. Dairy J. $17: 275-288$.

Gallier, S., D. Gragson, R. Jiménez-Flores, and D. W. Everett. 2012. $\beta$-casein-phospholipid monolayers as model systems to understand lipid-protein interactions in the milk fat globule membrane. Int. Dairy J. 22:58-65.

Gatellier, P., and V. Santé-Lhoutellier. 2009. Digestion study of proteins from cooked meat using an enzymatic microreactor. Meat Sci. 81:405-409.

Habte, H. H., C. de Beer, Z. E. Lotz, M. G. Tyler, D. Kahn, and A. S. Mall. 2008. Inhibition of human immunodeficiency virus type 1 activity by purified human breast milk mucin (MUC1) in an inhibition assay. Neonatology 93:162-170.

Hamosh, M., J. A. Peterson, T. R. Henderson, C. D. Scallan, R. Kiwan, R. L. Ceriani, M. Armand, N. R. Mehta, and P. Hamosh. 1999. Protective function of human milk: The milk fat globule. Semin. Perinatol. 23:242-249.

Hanisch, F. G., M. Jovanovic, and J. Peter-Katalinic. 2001. Glycoprotein identification and localization of $O$-glycosylation sites by mass 
spectrometric analysis of deglycosylated/alkylaminylated peptide fragments. Anal. Biochem. 290:47-59.

Heid, H. W., M. Schnölzer, and T. W. Keenan. 1996. Adipocyte differentiation-related protein is secreted into milk as a constituent of milk lipid globule membrane. Biochem. J. 320:1025-1030.

Inagaki, M., S. Nagai, T. Yabe, S. Nagaoka, N. Minamoto, T. Takahashi, T. Matsuda, O. Nakagomi, T. Nakagomi, T. Ebina, and Y. Kanamaru. 2010. The bovine lactophorin c-terminal fragment and pas6/7 were both potent in the inhibition of human rotavirus replication in cultured epithelial cells and the prevention of experimental gastroenteritis. Biosci. Biotechnol. Biochem. 74:1386-1390.

Judd, R. C. 2002. SDS-polyacrylamide gel electrophoresis of peptides. Pages 73-79 in The Protein Protocols Handbook. 2nd ed. J. M. Walker, ed. Humana Press, Totowa, NJ.

Kanno, C., and D.-H. Kim. 1990. A simple procedure for the preparation of bovine milk fat globule membrane and a comparison of its composition, enzymatic activities, and electrophoretic properties with those prepared by other methods. Agric. Biol. Chem. 54:2845-2854.

Kobylka, D., and K. L. Carraway. 1973. Proteolytic digestion of proteins of the milk fat globule membrane. Biochim. Biophys. Acta 307:133-140.

Kvistgaard, A. S., L. T. Pallesen, C. F. Arias, S. Lopez, T. E. Petersen, C. W. Heegaard, and J. T. Rasmussen. 2004. Inhibitory effects of human and bovine milk constituents on rotavirus infections. J. Dairy Sci. 87:4088-4096.

Le, T. T., J. Miocinovic, J. Van Camp, B. Devreese, K. Struijs, T. Van de Wiele, and K. Dewettinck. 2011. Isolation and applications of milk fat globule membrane material: Isolation from buttermilk and butter serum. Commun. Agric. Appl. Biol. Sci. 76:111-114.

Le, T. T., J. Van Camp, R. Rombaut, F. van Leeckwyck, and K. Dewettinck. 2009. Effect of washing conditions on the recovery of milk fat globule membrane proteins during the isolation of milk fat globule membrane from milk. J. Dairy Sci. 92:3592-3603

Mather, I. H. 2000. A review and proposed nomenclature for major proteins of the milk-fat globule membrane. J. Dairy Sci. 83:203247.

Mather, I. H., and T. W. Keenan. 1975. Studies on the structure of milk fat globule membrane. J. Membr. Biol. 21:65-85.

Parker, P., L. Sando, R. Pearson, K. Kongsuwan, R. L. Tellam, and S. Smith. 2010. Bovine Muc1 inhibits binding of enteric bacteria to Caco-2 cells. Glycoconj. J. 27:89-97.

Patton, S. 1994. Detection of large fragments of the human-milk mucin MUC-1 in feces of breast-fed infants. J. Pediatr. Gastroenterol. Nutr. 18:225-230.

Patton, S., and R. S. Patton. 1990. Genetic-polymorphism of PAS-I, the mucin-like glycoprotein of bovine milk fat globule membrane. J. Dairy Sci. 73:3567-3574

Perman, J. A., and S. Modler. 1982. Glycoproteins as substrates for production of hydrogen and methane by colonic bacterial-flora. Gastroenterology 83:388-393.

Peterson, J. A., M. Hamosh, C. D. Scallan, R. L. Ceriani, T. R. Henderson, N. R. Mehta, M. Armand, and P. Hamosh. 1998. Milk fat globule glycoproteins in human milk and in gastric aspirates of mother's milk-fed preterm infants. Pediatr. Res. 44:499-506.

Rombaut, R., V. Dejonckheere, and K. Dewettinck. 2007. Filtration of milk fat globule membrane fragments from acid buttermilk cheese whey. J. Dairy Sci. 90:1662-1673.
Ruvoën-Clouet, N., E. Mas, S. Marionneau, P. Guillon, D. Lombardo, and J. L. Pendu. 2006. Bile-salt-stimulated lipase and mucins from milk of 'secretor' mothers inhibit the binding of Norwalk virus capsids to their carbohydrate ligands. Biochem. J. 393:627-634.

Saeland, E., M. A. W. P. de Jong, A. A. Nabatov, H. Kalay, T. B. H. Geijtenbeek, and Y. van Kooyk. 2009. MUC1 in human milk blocks transmission of human immunodeficiency virus from dendritic cells to T cells. Mol. Immunol. 46:2309-2316.

Sando, L., R. Pearson, C. Gray, P. Parker, R. Hawken, P. C. Thomson, J. R. S. Meadows, K. Kongsuwan, S. Smith, and R. L. Tellam. 2009. Bovine Muc1 is a highly polymorphic gene encoding an extensively glycosylated mucin that binds bacteria. J. Dairy Sci. 92:5276-5291.

Shahriar, F., M. Ngeleka, J. R. Gordon, and E. Simko. 2006. Identification by mass spectroscopy of F4ac-fimbrial-binding proteins in porcine milk and characterization of lactadherin as an inhibitor of F4ac-positive Escherichia coli attachment to intestinal villi in vitro. Dev. Comp. Immunol. 30:723-734.

Shimizu, M., K. Yamauchi, and C. Kanno. 1979. Proteolytic digestion of milk fat globule membrane proteins. Milchwissenschaft 34:666-668.

Singh, H. 2006. The milk fat globule membrane-A biophysical system for food applications. Curr. Opin. Colloid Interface Sci. 11:154163.

Van de Wiele, T. R., W. Verstraete, and S. D. Siciliano. 2004. Polycyclic aromatic hydrocarbon release from a soil matrix in the in vitro gastrointestinal tract. J. Environ. Qual. 33:1343-1353.

Vanderghem, C., F. Francis, S. Danthine, C. Deroanne, M. Paquot, E. De Pauw, and C. Blecker. 2011. Study on the susceptibility of the bovine milk fat globule membrane proteins to enzymatic hydrolysis and organization of some of the proteins. Int. Dairy J. 21:312-318.

Vanrobaeys, F., R. Van Coster, G. Dhondt, B. Devreese, and J. Van Beeumen. 2005. Profiling of myelin proteins by 2D-gel electrophoresis and multidimensional liquid chromatography coupled to MALDI TOF-TOF mass spectrometry. J. Proteome Res. 4:22832293

Vermeirssen, V., J. Van Camp, L. Devos, and W. Verstraete. 2003. Release of angiotensin I converting enzyme (ACE) inhibitory activity during in vitro gastrointestinal digestion: From batch experiment to semicontinuous model. J. Agric. Food Chem. 51:5680-5687.

Walstra, P. 1985. Some comments on the isolation of fat globule membrane material. J. Dairy Res. 52:309-312.

Walstra, P., J. T. M. Wouters, and T. J. Geurts. 2006. Dairy Science and Technology. 2nd ed. CRC Press, Boca Raton, FL.

Wang, X., S. Hirmo, R. Willén, and T. Wadström. 2001. Inhibition of Helicobacter pylori infection by bovine milk glycoconjugates in a BALB/cA mouse model. J. Med. Microbiol. 50:430-435.

Watkins, J. B. 1985. Lipid digestion and absorption. Pediatrics $75: 151-156$

Yabe, U., C. Sato, T. Matsuda, and K. Kitajima. 2003. Polysialic acid in human milk. CD36 is a new member of mammalian polysialic acid-containing glycoprotein. J. Biol. Chem. 278:13875-13880.

Ye, A., J. Cui, and H. Singh. 2011. Proteolysis of milk fat globule membrane proteins during in vitro gastric digestion of milk. J. Dairy Sci. 94:2762-2770. 